\title{
Study of Tao Xingzhi's View on Life Education
}

\author{
Ziwen Tang \\ Xi'an Shiyou University, Faculty of Humanities, Xi'an, 710065, China
}

tzwmosquito@sina.cn

\begin{abstract}
Tao Xingzhi is one of the most famous educators in modern China. The concept of life education is one of the most important components of his education ideological system. It is a comprehensive system ranging from the education content and methods to the purpose of education. The concept of "life is education" and "society are school" are its core point. The goal, content, the method of life education have been elaborated. These educational theories are still shining today, and still have important reference value for China's current educational innovation, cultural innovation and the implementation of the strategy of strengthening educational power.
\end{abstract}

Keywords: Tao Xingzhi's View; Concept of Life Education; Educational Innovation.

\section{Introduction}

Life education is an indispensable part of Tao Xingzhi's education ideological system. Throughout his life of educational research and practice, his life education concept has experienced a process from brewing to maturity to perfection. Tao Xingzhi's view on life education thought means an education of life, by life and for life. In his opinion,education is life itself, so it can be educated everywhere in life.Based on these previous theories, extend the three propositions of life education: life is education, society is school, the education method that named the unity of teaching learning and doing.From the history to the present, life education still maintains a strong vitality, which is worth learning from today.

\section{Taking Life as the Teaching Content}

Tao Xingzhi's view of life education is a comprehensive system containing the educational connotation of educational content and methods, and then to the purpose of education. "Life is education" and "society is school" are its core thoughts.He proposed: " We should use all the things needed for the environment and spread in schools. According to the principle of integrating learning and education, train people with special talents, so that they can guide students to enjoy all the environment according to the needs of their ability and meet the needs of the environment."[1] Tao Xingzhi's view of life education emphasizes the importance of the word" environment " repeatedly, which is to require students to learn from reality, learn from life, and then apply what they have learned to life. This thought reflects Tao Xingzhi's profound reflection on the current situation of normal education which far from the actual life at that time. He stressed that life is the foundation of education, "our real life, is all of our course; our course is our real life"[2]. Life determines education, and the nature and content of life determine the nature and content of education. Only in this way can students learn from life and use it in life.

In order to realize the concept of learning in life and learning everywhere in life, Tao Xingzhi proposed the "artist system" as a special teaching form. This is a very innovative teaching form based on life practice, he pointed out: "The current normal education divides academic theory and internship into two things, teaching students to be nerds, and the students taught are the same as ordinary middle schools.", Then, "most people with normal training, still can not build a admirable school"."There are two ways to learn to be teachers, one is to learn, the other is to visit friends." [3]

The "art" of "Art friends" refers to a skilled man, and the "friends" refers to that there is no difference in identity between teachers and students. There is only a difference in craftsmanship. They learn from each other and make progress together. There are no artificial boundaries and barriers between teachers and students, which means learning everywhere and everyone in life. In addition, 
Tao Xingzhi advocated that student should be happy and good at understanding and receiving education from life. in his opinion "Students read for their livelihoods, not for living" [4] is the learning view that Tao Xingzhi has repeatedly denied. He believed that students do not only learn by books, and teachers do not only teach with books, both teachers and students have their own merits in their lives.He said that "we believe that no teacher is authoritative, only instructors with more experience or knowledge."[5] As can be seen from the "art friend system" created by Tao Xingzhi and his expression of teachers and students, it can be seen that the education proposed by Tao Xingzhi is a kind of education that needs to constantly absorb nutrients in life and learn knowledge and experience from anyone.

\section{Combination of Teaching, Learning and Practicing as the Principle}

As the motto of Xiaozhuang Normal School, "Combination of teaching, learning and doing" is the main teaching principle in the life education of Tao Xingzhi's. In his opinion, teaching, learning and practicing should be fully integrated in the classroom. He said "We want to carry out teaching in practice and let students learn in practice. Whether teaching in practice is the most important criterion. "[6] It can be seen that practice is the center in the teaching process. In practice-centered teaching activities, practice has not only become the main means of carrying out teaching activities, but also has become an important basis for the final test of the teaching effect, and has become prerequisites for carrying out the next stage of work smoothly. Teachers and students promote mutual progress through teaching, learning and doing, and ultimately realize the common growth of teachers and students.

In order to carrying out teaching activities specifically and pointedly, Tao Xingzhi summarized life education into five parts according to its specific contents. One is the central primary school activities part, which is divided into Chinese arithmetic group, citizens group, health group, nature group, gardening group and game entertainment.Normal university students choose one or two groups to participate in the students' learning process and interact with the students to complete the whole teaching process. The second is Daily Management part, including the secretarial, accounting, chores, cleaning and other work of the whole school are guided by the instructor to students". Only in this way can it be ensured that rural teachers can conduct teaching activities in schools in any environment.The third is nature learning part, which includes agriculture, afforestation, basic handwork, hygiene and so on, that means students learn everything in the natural environment through practice.The fourth is the social environment transformed part,which including village autonomy, public education, cooperative organizations, rural investigation and farmers entertainment in order to solve the problem of getting along with the human and natural environment. The fifth is self-learning part, which means normal students should develop the habit of automatic planning and decision-making.[7] It can be seen that in Tao Xingzhi's life education system, the integration of teaching and learning is not only the most basic educational principle, but also the core element of organizational teaching, from individuals to others, from nature to society, from life to survival, and all aspects of life. All need to be combined through teaching to achieve the purpose of learning.

\section{To Cultivate the True, the Good and the Beautiful as the Teaching Goal}

Tao Xingzhi advocated that the goal of life education should be from the perspective of both students and teachers. For students, they have to become a kind of "truth, goodness and beauty" with innovative ability. This kind of person is a person who is good at thinking and has the courage to practice. When this kind of person is using his brain, he will also put it into practice. When he is in practice, he will also use his brain to think actively. For teachers, "real, kind, and beautiful living people" are what teachers want to create, as he said in the "Creation Manifesto": "What they want to create is a real, beautiful, and beautiful life. People. The real, beautiful, and beautiful living person is our God and our lover."[8] Tao Xingzhi believes that the purpose of education is to cultivate people 
with innovative ability, because old China, which was in a semi-feudal and semi-colonial country at that time, lacked this kind of creative spirit, and it was also indispensable for the Chinese nation to truly stand up in the world. Therefore, the creative spirit is also the spirit that we should promote and respect.

A "truth, goodness, and beauty" is a person who has comprehensive development of morality, intelligence, body, and beauty, and refers to a person with a perfect personality. Therefore, Tao Xingzhi's expectations of creating educational goals far exceeded the requirements of his era, which was not easy to achieve in China at that time. Although his creative education goal cannot be achieved, we all recognize the progressiveness and advanced nature of this theory. The goal of today's creative education is to cultivate creative talents, newcomers who have outstanding performance in ideals, ethics, culture and discipline. As Tao Xingzhi said, these people are "truth, good and beautiful living people."

\section{To Transform the Society is the Ultimate Goal of Life Education}

The life education proposed by Tao Xingzhi is a complete ideological system. It includes taking the life practice of students as the basis, taking life education theory as the educational content, emphasizing the teaching principle of integrating teaching and learning, and setting up special central schools as practice bases for normal students to pass on the concept of living education to future teachers,cultivate a series of contents such as "living teachers" full of vitality, and then cultivate "nationals with vitality".This is an indispensable teaching logic, but also it is also a complete teaching practice system.As for how to cultivate "living" teachers through life education, he proposed that rural teachers should be trained by opening up "live" rural normal schools, and these rural teachers should drive the development of rural life education, so as to improve the overall cultural quality of the countryside, and finally realize the ultimate ideal of transforming the society.He proposed that "we should live from the central rural schools, rural teachers from live central schools, live rural teachers", " live rural teachers should have the skill of farmers, scientific mind, and transform the spirit of society.Living rural education should have a way to live, living method is to integrate teaching; teaching method according to the method of learning, learning method according to do method, how to do, how to learn, how to teach, live rural education should use a living environment, without dead books."Tao Xingzhi for the understanding of the role of rural normal education, Tao Xingzhi has an incisive discussion."Rural normal schools have the mission of training rural teachers and transforming rural life."[9] How to achieve the goal of transforming rural life by training rural teachers, he believes: " Running schools and transforming society is one thing, not two things.

Reform of society without starting from running a school, it can not transform people's heart, it is not a radical way to transform society.On the other hand, running a school, without including the mission of transforming the society, is no purpose, meaningless, no anger.Therefore, education is the social transformation, and teachers are the leader of the social transformation.In the hands of the teacher, holding the fate of juveniles, and then holding the fate of the nation and mankind."[10] He closely combines education, transforming people's heart and transforming society.Education transforms the society through transforming the people and trains the people in transforming the society, which is the social role of education, as a rural normal education also has this function.From Tao Xingzhi understanding of rural normal education role is not difficult to see, for him to open a rural normal school is just a means, eventually hope to implement its life education concept, improve the old pedantic education concept, and then improve the national literacy to achieve education popularization, finally achieve the goal of education transformation society.

Tao Xingzhi's life education theory emphasizes that the education of students should not be limited to classrooms and textbooks, and teaching should not be too closed. If teaching is separated from society and life, good educational results will not be achieved. Tao Xingzhi advocates open teaching. Learning content comes from life but is higher than life. Therefore, in order to cultivate students' creativity, they need to be integrated into life, stimulate students' life experience, and enable them to 
apply teaching content to their lives. It can play a good role in guiding students, and the creativity of students can be further stimulated, thereby improving teaching efficiency.Tao Xingzhi's life education idea takes life as the core and the needs of life; life education is the main content; and teaching integration is the main teaching method.Tao Xingzhi closely connects life with education, society and school. Through the dissemination of life education concept, he tries to change the old education that separates society from school, education and life.Emphasize from reality, guide students from life, study the beneficial part of life, although the time is changed, but this thought is of great significance to the current education reform.

\section{References}

[1] Institute of Educational Science, Central China Normal University. The Complete Works of Tao Xingzhi (Volume 1). Changsha: Hunan Education Press House, 1984 edition, p.639.

[2] Gu Mingyuan. Tao Xingzhi Collection (Volume 1) [M]. Beijing: Education Science Press, 2011 edition, p.243.

[3] Tao Xingzhi. Education Transformation in China [M]. Beijing: Commercial Press, 2014 edition, p.123.

[4] Institute of Educational Science, Central China Normal University. The Complete Works of Tao Xingzhi (Volume 2) [M]. Changsha: Hunan Education Press House, 1984 edition, p.34-35.

[5] Institute of Educational Science, Central China Normal University. The Complete Works of Tao Xingzhi (Volume 2) [M]. Changsha: Hunan Education Publishing House, 1984 edition, p.10.

[6] Tao Xingzhi. Education Transformation in China [M]. Beijing: Commercial Press, 2014 edition, p.102.

[7] Institute of Educational Science, Central China Normal University. The Complete Works of Tao Xingzhi (Volume 2) [M]. Changsha: Hunan Education Press House, 1984 edition, p.33-34.

[8] Institute of Educational Science, Central China Normal University. The Complete Works of Tao Xingzhi (Volume 3) [M]. Changsha: Hunan Education Press House, 1984 edition, p.482.

[9] Gu Mingyuan. Tao Xingzhi Collection (Volume 1) [M]. Beijing: Education Science Press, 2011 edition, p.229.

[10] Institute of Educational Science, Central China Normal University. The Complete Works of Tao Xingzhi (Volume 2) [M]. Changsha: Hunan Education Press House, 1984 edition, p.128. 